\title{
Storage and persistence of a candidate fungal biopesticide for use against adult malaria vectors
}

\author{
Simon Blanford ${ }^{1,2^{*}}$, Nina E Jenkins ${ }^{2}$, Riann Christian ${ }^{3,4}$, Brian HK Chan ${ }^{1,2}$, Luisa Nardini ${ }^{3,4}$, Michael Osae ${ }^{3}$, \\ Lizette Koekemoer ${ }^{3,4}$, Maureen Coetzee ${ }^{3,4}$, Andrew F Read ${ }^{1,2,5}$ and Matthew B Thomas ${ }^{4}$
}

\begin{abstract}
Background: New products aimed at augmenting or replacing chemical insecticides must have operational profiles that include both high efficacy in reducing vector numbers and/or blocking parasite transmission and be long lasting following application. Research aimed at developing fungal spores as a biopesticide for vector control have shown considerable potential yet have not been directly assessed for their viability after long-term storage or following application in the field.
\end{abstract}

Methods: Spores from a single production run of the entomopathogenic fungi Beauveria bassiana were dried and then stored under refrigeration at $7^{\circ} \mathrm{C}$. After 585 days these spores were sub-sampled and placed at either $22^{\circ} \mathrm{C}$, $26^{\circ} \mathrm{C}$ or $32^{\circ} \mathrm{C}$ still sealed in packaging (closed storage) or in open beakers and exposed to the $80 \%$ relative humidity of the incubator they were kept in. Samples were subsequently taken from these treatments over a further 165 days to assess viability. Spores from the same production run were also used to test their persistence following application to three different substrates, clay, cement and wood, using a hand held sprayer. The experiments were conducted at two different institutes with one using adult female Anopheles stephensi and the other adult female Anopheles gambiae. Mosquitoes were exposed to the treated substrates for one hour before being removed and their survival monitored for the next 14 days. Assays were performed at monthly intervals over a maximum seven months.

Results: Spore storage under refrigeration resulted in no loss of spore viability over more than two years. Spore viability of those samples kept under open and closed storage was highly dependent on the incubation temperature with higher temperatures decreasing viability more rapidly than cooler temperatures. Mosquito survival following exposure was dependent on substrate type. Spore persistence on the clay substrate was greatest achieving $80 \%$ population reduction for four months against An. stephensi and for at least five months against Anopheles gambiae. Cement and wood substrates had more variable mortality with the highest spore persistence being two to three months for the two substrates respectively.

Conclusions: Spore shelf-life under refrigeration surpassed the standard two year shelf-life expected of a mosquito control product. Removal to a variety of temperatures under either closed or open storage indicated that samples sent out from refrigeration should be deployed rapidly in control operations to avoid loss of viability. Spore persistence following application onto clay surfaces was comparable to a number of chemical insecticides in common use. Persistence on cement and wood was shorter but in one assay still comparable to some organophosphate and pyrethroid insecticides. Optimized formulations could be expected to improve spore persistence still further.

\footnotetext{
*Correspondence: stb13@psu.edu

${ }^{1}$ Center for Infectious Disease Dynamics, Penn State University, Department

of Biology, Mueller Laboratory, University Park, PA 16802, USA

${ }^{2}$ Center for Infectious Disease Dynamics, Department of Entomology, Penn

State University, Merkle Lab, University Park, PA 16802, USA

Full list of author information is available at the end of the article
}

\section{Biomed Central}

(C) 2012 Blanford et al.; licensee BioMed Central Ltd. This is an Open Access article distributed under the terms of the Creative Commons Attribution License (http://creativecommons.org/licenses/by/2.0), which permits unrestricted use, distribution, and reproduction in any medium, provided the original work is properly cited. 


\section{Background}

The increasing incidence of resistance to chemical insecticides by malaria mosquito vectors [1-5] has prompted a wide-ranging search for alternative control tools. This research includes various projects investigating the control potential of a range of insect pathogens and parasites [6-10]. Among these novel biocontrol approaches, the use of entomopathogenic fungi formulated as biopesticides has received considerable attention [11-20]. Numerous studies show that fungi can infect adult mosquitoes when applied to a range of substrates, suggesting potential for use as Indoor Residual Sprays (IRS) $[6,7,20]$, or via novel delivery strategies such as impregnated eve curtains [19], resting targets [11,21] or even impregnated bed nets [20,22]. While slower acting than conventional chemical insecticides, fungal infection has been shown to cause substantial reduction in transmission potential of a range of vector species [6,7,23-26]. Further, insecticide resistant mosquitoes appear to remain fully susceptible to fungal infection $[7,17,18]$.

To date, most studies exploring fungal infection in adult mosquitoes have focused on direct measures of efficacy (e.g. mosquito mortality, biting rate, fecundity etc.) and on the whole, the data are encouraging. However, ultimate development of a practical control tool requires understanding of several performance metrics and not just efficacy. Key among these is product stability, including the storage potential of spores (the active ingredient) post-production and the persistence of spores following application.

The World Health Organization stipulates that chemical insecticides used for mosquito vector control should be able to be stored for two years without significant loss in efficacy of the active ingredient $[27,28]$. Previous studies on entomopathogenic fungi suggest that the strain, the production conditions, temperature, humidity and spore moisture content can all influence fungal viability during long-term storage [29-34]. Under ideal conditions of low temperature $\left(c .5^{\circ} \mathrm{C}\right)$ and low spore moisture content $(<5 \%)$, entomopathogenic fungi have been shown to store with minimal loss of viability for over 2 years, as long as initial viability is high [30]. Such longevity looks promising but determining the storage potential of particular candidate strains is an important step in evaluating operational potential of the mosquito biopesticide approach.

With respect to persistence, how long a product needs to remain viable after treatment will likely depend on the delivery system. Intuitively, the longer a product lasts the better but there are no precedents for novel delivery strategies such as point source applications on a small resting target $[19,21]$ and in principle, a product could be re-applied relatively frequently without major disruption to behavior or substantial cost. For established approaches such as IRS, on the other hand, there are targets set by WHO based on existing product profiles. At present, the current insecticides approved for use in IRS by WHO persist for 2-6 months after application, with DDT setting the 'gold standard' [35-37].

Studies investigating persistence of fungal spores have largely focused on decay rates of biopesticides applied in agricultural settings. In many cases infective half-lives are on the order of days or weeks [38-40]. The chief reason for this rapid decay is that fungal spores are very quickly deactivated by solar (UV) radiation [41]. When spores are applied in more protected environments, such as soil inoculation, persistence can be extended to months or even years $[42,43]$. Since the application of fungal biopesticides for mosquito control will most likely be in indoor (or at least shaded) environments, UV radiation is unlikely to be a constraint suggesting that persistence might good. Again, however, it is necessary to determine this for any candidate biopesticide.

The aim of the current study is to examine the storage and persistence of an isolate of Beauveria bassiana that is one of the leading candidates for development as a mosquito biopesticide product. The viability of spores maintained under a range of conditions in the lab was quantified to determine storage potential at different points along a pesticide 'supply chain'. Spores retained high viability for over two years under good storage conditions. Transfer to less ideal conditions after this period resulted in decline in viability over a period of one to three months depending on temperature. Product persistence on a range of substrates simulating an IRS-type application was examined by conducting one set of assays with $A n$. stephensi and a second set with An. gambiae. Fungal spray residues remained infective on clay substrates for 4-6 months, performing much better than a pyrethroid toxic standard. Performance could be extended if mosquitoes received more than one exposure. Persistence on wood and concrete was less good, and varied from as little as 1 week up to 2 or 3 months depending on the particular assay. The results are discussed in the context of further research and development priorities to progress the fungal biopesticide approach towards operational use. There is considerable scope to increase persistence with appropriate formulation chemistry.

\section{Methods}

\section{Fungal maintenance, production and storage methods} and tests

Beauveria bassiana isolate I93-825 was maintained in long-term storage at $-80^{\circ} \mathrm{C}$ on microporous beads (ProLab Diagnostics, Austin, Texas, USA). Prior to use, the fungus was recovered by placing one or two beads onto Potato dextrose agar (Oxoid, UK) or Sabouraud dextrose 
agar (Oxoid, UK) in $9 \mathrm{~cm}$ diameter Petri dishes or slopes in $25 \mathrm{ml}$ Universal bottles and incubated at $25^{\circ} \mathrm{C}$ for 10 days.

\section{Mass production}

Conidia were harvested from slopes or plates to make a spore suspension of approximately $1 \times 10^{6}$ spores $\mathrm{ml}^{-1}$ in sterile $0.05 \% \mathrm{w} / \mathrm{v}$ Tween 80 (Sigma) in distilled water. One $\mathrm{ml}$ of this suspension was then used to inoculate 75 $\mathrm{ml}$ sterile liquid culture medium ( $4 \%$ d-Glucose, $2 \%$ yeast extract [Oxoid, UK] in tap water), in $250 \mathrm{ml}$ Erlenmyer flasks. Flasks were incubated on a rotary shaker $(200 \mathrm{rpm})$ at $22^{\circ} \mathrm{C}$ for 3 days.
Organic barley flakes were weighed into mushroom spawn bags (Unicorn, Garland, Texas, USA) with $1 \mathrm{~kg}$ per bag. $600 \mathrm{ml}$ of tap water was then added to each bag and the contents mixed by hand to ensure even absorption of the water. The spawn bags were then placed inside autoclave bags for protection and autoclaved for 30 $\min$ at $121^{\circ} \mathrm{C}$. Once cool the bags were inoculated under aseptic conditions with $75 \mathrm{ml}$ of the 3-day-old liquid medium (above) plus $75 \mathrm{ml}$ of sterile water to achieve a final moisture content of approximately $48 \%$. The inoculated bags were carefully massaged to ensure even distribution of the inoculum. The bags were then sealed and incubated on shelves for 10 days at $22^{\circ} \mathrm{C}$. Following

\section{A) Closed Storage}

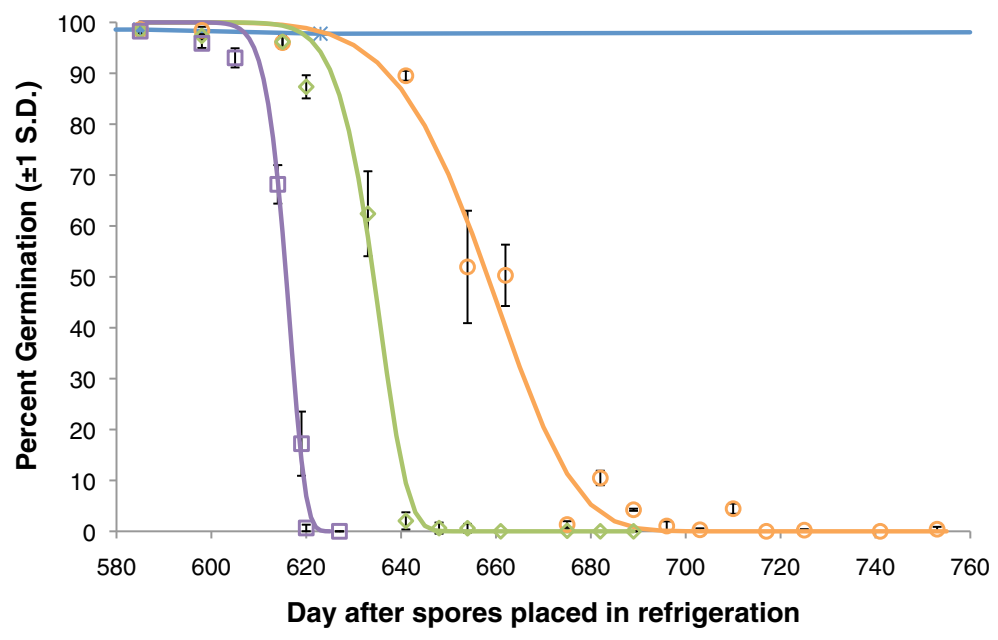

B) Open storage

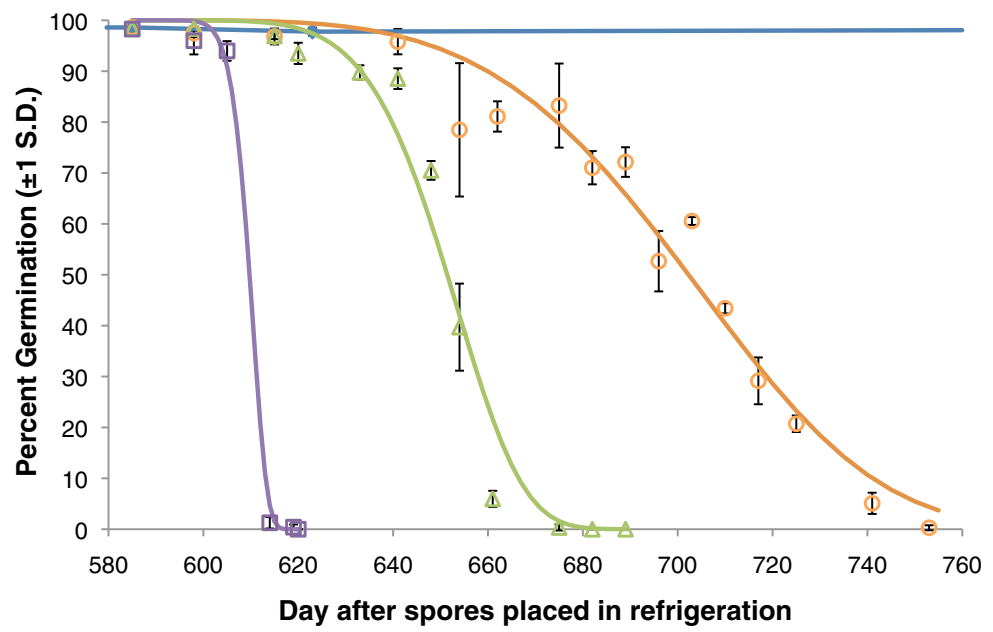

Figure 1 Germination (percent) of spores of Beauveria bassiana after long term storage under varying conditions. A) Germination of spores removed from $7{ }^{\circ} \mathrm{C}$ after 580 days and subsequently maintained at $22^{\circ} \mathrm{C}, 26^{\circ} \mathrm{C}$ or $32^{\circ} \mathrm{C}$. B) As for $\mathbf{A}$ ) but spores were taken from the refrigeration conditions after 580 days and subsequently maintained in open glass beakers placed in incubators with relative humidity at $80 \%$ and temperatures of $22^{\circ} \mathrm{C}, 26^{\circ} \mathrm{C}$ and $32^{\circ} \mathrm{C}$. Blue line is for germination of spores at $7^{\circ} \mathrm{C}$ across the monitoring period (same for both graphs as a reference), orange points spores kept at $22^{\circ} \mathrm{C}$, green points spores kept at $26^{\circ} \mathrm{C}$ and purple points spores kept at $32^{\circ} \mathrm{C}$. Curves are Weibull survival functions fitted through the germination data at each temperature. $R^{2}$ and parameter values can be found in Table 1. 
Table 1 Model parameters and survival data for spore viability when kept in sealed or open storage at different temperatures

\begin{tabular}{|c|c|c|c|c|c|c|}
\hline \multirow[t]{2}{*}{ Treatment } & \multirow{2}{*}{$\begin{array}{c}\text { Storage } \\
\text { temperature }\end{array}$} & \multicolumn{3}{|c|}{ Weibull parameters } & \multicolumn{2}{|c|}{ Spore survival (days) } \\
\hline & & A & G & $R^{2}$ & $\mathrm{LT}_{20}$ & $\mathrm{LT}_{50}$ \\
\hline \multirow[t]{3}{*}{ Closed storage } & $22^{\circ} \mathrm{C}$ & $1.53 \times 10^{-10}$ & 5.578 & 0.99 & 60 & 73 \\
\hline & $26^{\circ} \mathrm{C}$ & $6.05 \times 10^{-16}$ & 9.477 & 0.99 & 44 & 49 \\
\hline & $32^{\circ} \mathrm{C}$ & $1.78 \times 10^{-15}$ & 10.49 & 0.99 & 28 & 31 \\
\hline \multirow[t]{3}{*}{ Open Storage } & $22^{\circ} \mathrm{C}$ & $5.85 \times 10^{-9}$ & 4.203 & 0.96 & 90 & 117 \\
\hline & $26^{\circ} \mathrm{C}$ & $7.76 \times 10^{-11}$ & 5.883 & 0.98 & 55 & 67 \\
\hline & $32^{\circ} \mathrm{C}$ & $5.94 \times 10^{-13}$ & 9.357 & 0.99 & 22 & 25 \\
\hline
\end{tabular}

Spores were moved from refrigeration after 585 days and sub-sampled at intervals until germination rates had declined to zero. Details of the Weibull survival function are given in the main text.

incubation, the bags were opened in a reverse flow cabinet (Labconco, USA) and the contents transferred to brown paper bags for drying. The paper bags were placed in a dehumidified room for 4 days $\left(22^{\circ} \mathrm{C}\right)$, until the sporulated substrate reached $<20 \%$ moisture content. The spores were then harvested from the barley flakes using a Mycoharvester (Acis Manufacturing, Devon, UK). The harvested spores were placed in glass dishes and further dried in a desiccator over dry silica gel at $22^{\circ} \mathrm{C}$. Once the spore powder reached $5 \%$ moisture content, a small sample was taken for quality analysis and the remaining powder was sealed in foil laminated sachets (P39 moisture barrier film) and stored at $7^{\circ} \mathrm{C}$. The following storage and persistence studies used spores from a large production run that had been in storage for 585 days prior to the onset of testing. At this point spores were $98 \%$ viable (see germination test methods below).

\section{Long-term storage}

Dried spores were taken from storage and distributed into small $(5 \times 5 \mathrm{~cm})$ hermetically sealed foil laminate sachets. A subset was placed back under the original

Table 2 Anopheles stephensi survival after exposure to clay tiles

\begin{tabular}{|c|c|c|c|c|}
\hline $\begin{array}{l}\text { Time after } \\
\text { exposure }\end{array}$ & Treatment & $\begin{array}{l}\text { Median Lethal Time days } \\
(95 \% \text { C.I. })^{*}\end{array}$ & $\begin{array}{c}\text { Log rank statistic } \\
\text { (Significance compared to control) }\end{array}$ & $\begin{array}{l}\text { Time to } 80 \% \text { mortality days } \\
\text { ( } \pm 1 \text { SEM)* }\end{array}$ \\
\hline \multirow[t]{3}{*}{ Day 1} & Control & $10.0(9.05-10.95)$ & -—————— & $12.8( \pm 0.48)$ \\
\hline & Pyrethroid & $9.0(8.25-9.75)$ & $5.9(P=0.015)$ & $12.3( \pm 0.48)$ \\
\hline & B. bassiana & $4.0(3.74-4.26)$ & $164.1(P<0.001)$ & $5.0( \pm 0.00)$ \\
\hline \multirow[t]{3}{*}{ Week 1} & Control & $13.0(11.92-14.01)$ & -————— & Not achieved \\
\hline & Pyrethroid & $13.0(11.0-15.0)$ & $0.63(P=0.43)$ & Not achieved \\
\hline & B. bassiana & $4.0(3.73-4.27)$ & $107.5(P<0.001)$ & $5.3( \pm 0.25)$ \\
\hline \multirow[t]{3}{*}{ Month 1} & Control & $13.0(12.23-13.77)$ & -二-二-—- & $12.3( \pm 0.25)$ \\
\hline & Pyrethroid & $14.0(13.52-14.48)$ & $2.05(P=0.15)$ & $12.5( \pm 0.96)$ \\
\hline & B. bassiana & $5.0(4.77-5.23)$ & $190.2(P<0.001)$ & $5.0( \pm 0.00)$ \\
\hline \multirow[t]{3}{*}{ Month 2} & Control & $14.0(12.88-15.12)$ & -二-——- & Not achieved \\
\hline & Pyrethroid & $13.0(11.20-14.80)$ & $0.85(P=0.36)$ & Not achieved \\
\hline & B. bassiana & $5.0(4.68-5.32)$ & $162.37(P<0.001)$ & $6.0( \pm 0.00)$ \\
\hline \multirow[t]{3}{*}{ Month 3} & Control & $10.0(9.07-10.93)$ & -—-二-—- & Not achieved \\
\hline & Pyrethroid & $9.0(8.25-9.75)$ & $5.7(P=0.017)$ & Not achieved \\
\hline & B. bassiana & $4.0(3.74-4.26)$ & $168.7(P<0.001)$ & $6.5( \pm 0.50)$ \\
\hline \multirow[t]{2}{*}{ Month 4} & Control & Not achieved & 一-二-二— & Not achieved \\
\hline & B. bassiana & $9.0(8.40-9.60)$ & $144.5(P<0.001)$ & $12.3( \pm 1.03)$ \\
\hline \multirow[t]{3}{*}{ Month 5} & Control & Not achieved & -二-二-—- & Not achieved \\
\hline & B. bassiana & Not achieved & $18.7(P<0.001)$ & Not achieved \\
\hline & $\begin{array}{l}\text { B. bassiana } \\
\text { (repeat exposure) }\end{array}$ & $11.0(10.42-11.58)$ & $119.8(P<0.001)$ & $13.3( \pm 0.48)$ \\
\hline
\end{tabular}


storage conditions and their germination measured at the end of the study period (day 750).

Other sachets were placed in three environmental chambers maintained at $22^{\circ} \mathrm{C}, 26^{\circ} \mathrm{C}$ or $32^{\circ} \mathrm{C}$ to simulate transfer of spores from long-term storage into labs or warehouses for distribution or formulation. Individual sachets were removed at approximately weekly intervals and destructively sampled for germination.

To investigate the interaction between temperature and humidity, other spores were removed from storage and placed in open $200 \mathrm{ml}$ glass beakers (10 g dry spore powder per beaker) and then transferred to the environmental chambers set at 22,26 and $32^{\circ} \mathrm{C}$. Because the beakers were open, these spores were exposed to ambient relative humidity in the chambers, which was set at $80 \%$ to represent typical tropical conditions. Viability was checked over time by taking sub-samples of spore powder from the beakers at approximately weekly intervals to test germination rate.

\section{Germination tests}

To assess viability of spores, a small sample of spore powder was suspended in Isopar $\mathrm{M}$ (ExxonMobil) to a concentration of approximately $1 \times 10^{7} \mathrm{sp} \mathrm{m}{ }^{-1}$. One drop of this suspension was transferred onto SDA in 6 $\mathrm{cm}$ diameter Petri plates using a microspatular and

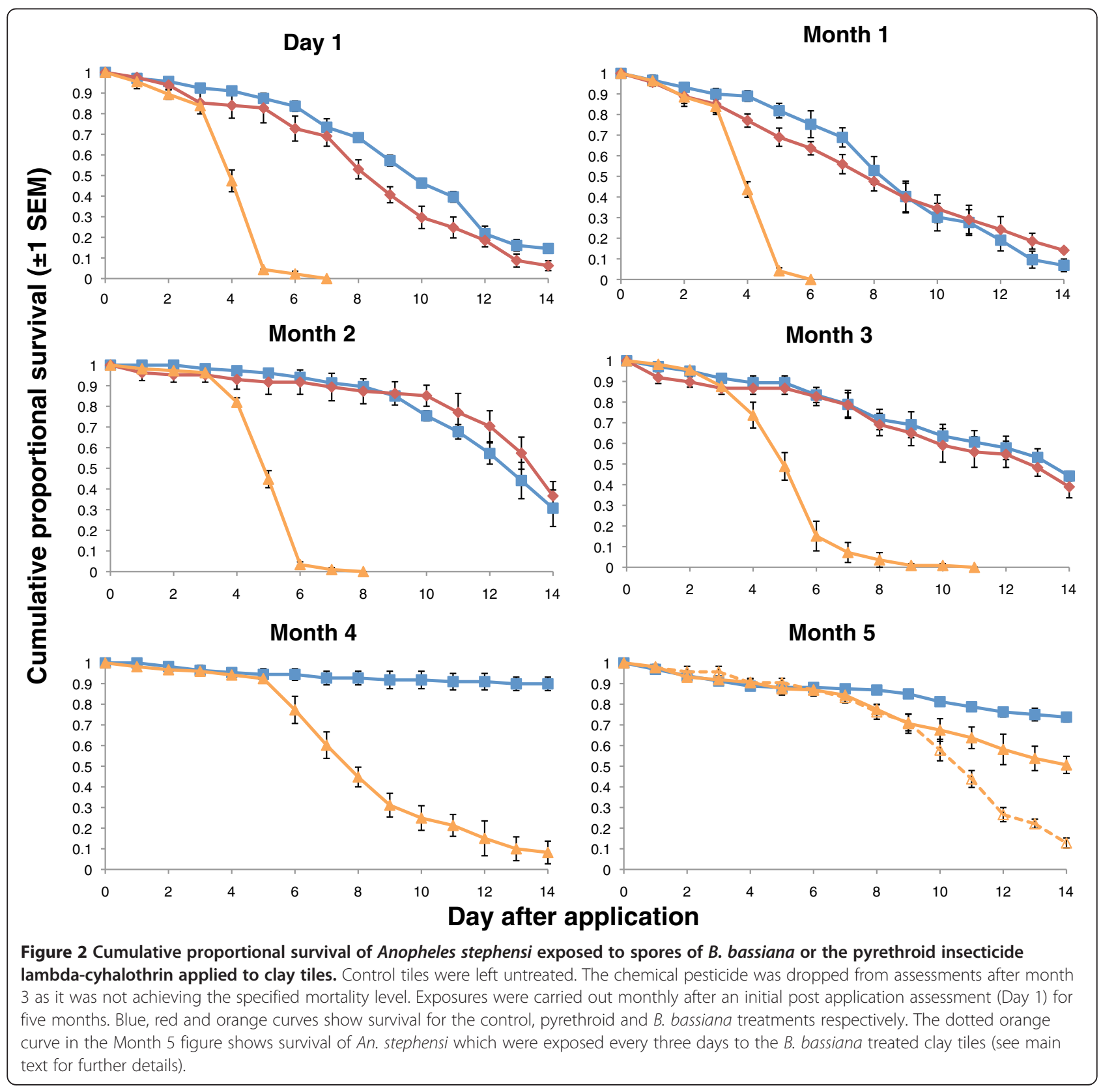


spread evenly over the surface of the agar. Three replicates were prepared for each sample time and incubated at $25^{\circ} \mathrm{C}$ for $20 \mathrm{hr}$. After incubation, the spores on the agar surface were examined under a compound microscope (at 500x magnification). Spores were counted as germinated if a germ was visibly protruding from the spore. All spores in each field of view were assessed. A total of at least 300 spores were counted per plate and viability was calculated as a percentage of the total.

\section{Fungal persistence after application Basic assay methods}

The World Health Organization Pesticide Evaluation Scheme (WHOPES) prescribes a set of standardized protocols for evaluating persistence of compounds for use in IRS [35]. Each compound must be applied to three different substrates (clay/mud, cement/concrete and wood) and mosquitoes exposed to the treated surfaces for one hour (depending on species) at different time points after application. For conventional fast acting chemical pesticides, the number of insects knocked down after the exposure period and then the number dead after 24 hours are recorded. The WHO cut-off point for acceptable mortality is $80 \%$. This general protocol was followed but with one important modification to account for the very different mode of action of fungal entomopathogens that cause mortality over a timeframe of 1-2 weeks rather than $24 \mathrm{~h}$ (note, that it takes about 14 days for the malaria parasite to develop within the mosquito, so that products with slower mortality can still provide excellent malaria control by shortening mosquito life span to prevent successful parasite incubation $[6,7,24-26]$. In line with earlier studies [6,7] we monitored mortality for 14 days, with persistence assessments discontinued when a product failed to achieve the $80 \%$ mortality endpoint. Persistence was assessed under standard WHOPES conditions of $26 \pm$ $2^{\circ} \mathrm{C}, 80 \pm 10 \% \mathrm{RH}$ and 12:12 day:night cycle.

\section{Test substrates}

Blocks of cement (Quickrete ${ }^{\circledR}$ ) and clay (White Earthenware; Clay-King Inc.), each $5 \mathrm{~mm}$ thick, were prepared in $15 \mathrm{~cm}$ Petri dishes and dried at $25 \pm 2{ }^{\circ} \mathrm{C}$ and $50 \pm 10 \%$ $\mathrm{RH}$ for at least 6 weeks prior to testing. A third substrate, wood tiles, $5 \mathrm{~mm}$ thick $16 \times 16 \mathrm{~cm}$ square blocks (birch plywood; Lowes Inc.), was also included. Following application all substrates were stored unsealed and therefore open to the test temperature and humidity

Table 3 Anopheles stephensi survival after exposure to cement tiles

\begin{tabular}{|c|c|c|c|c|}
\hline $\begin{array}{l}\text { Time after } \\
\text { exposure }\end{array}$ & Treatment & $\begin{array}{l}\text { Median Lethal Time days } \\
(95 \% \text { C.I. })^{*}\end{array}$ & $\begin{array}{c}\text { Log rank statistic } \\
\text { (Significance compared to control) }\end{array}$ & $\begin{array}{l}\text { Time to } 80 \% \text { mortality days } \\
( \pm 1 \text { SEM)* }\end{array}$ \\
\hline \multirow[t]{3}{*}{ Day 1} & Control & $11.0(9.89-12.11)$ & -—-———- & Not achieved \\
\hline & Pyrethroid & $6.0(4.77-7.23)$ & $58.5(P<0.001)$ & $10( \pm 0.82)$ \\
\hline & B. bassiana & $7.0(6.45-7.55)$ & $89.1(P<0.001)$ & $11.0( \pm 0.71)$ \\
\hline \multirow[t]{3}{*}{ Week 1} & Control & $12.0(10.55-13.45)$ & & Not achieved \\
\hline & Pyrethroid & Not achieved & $4.1(P=0.042)$ & Not achieved \\
\hline & B. bassiana & $7.0(5.99-8.02)$ & $42.2(P<0.001)$ & Not achieved \\
\hline \multirow[t]{3}{*}{ Month 1} & Control & $9.0(8.25-9.75)$ & ー-ー-—— & $12.8( \pm 0.63)$ \\
\hline & Pyrethroid & $9.0(8.27-9.73)$ & $0.96(P=0.33)$ & $12.0( \pm 0.71)$ \\
\hline & B. bassiana & $9.0(8.07-9.93)$ & $2.48(P=0.12)$ & $12.0( \pm 0.41)$ \\
\hline \multirow[t]{3}{*}{ Month 2} & Control & $13.0(12.36-13.64)$ & ーーーーーーー & Not achieved \\
\hline & Pyrethroid & $13.0(12.22-13.78)$ & $0.01(P=0.92)$ & Not achieved \\
\hline & B. bassiana & $8.0(7.33-8.67)$ & $52.63(P<0.001)$ & $12.0( \pm 0.58)$ \\
\hline \multirow[t]{3}{*}{ Month 3} & Control & $13.0(11.52-14.84)$ & -—————- & Not achieved \\
\hline & Pyrethroid & $11.0(8.72-13.28)$ & $1.8(P=0.18)$ & Not achieved \\
\hline & B. bassiana & $7.0(6.55-7.45)$ & $63.3(P<0.001)$ & $11.0( \pm 1.29)$ \\
\hline \multirow[t]{3}{*}{ Month 4} & Control & Not achieved & & Not achieved \\
\hline & Pyrethroid & -———-—— & -ーー-—— & -ー-ー-ー- \\
\hline & B. bassiana & Not achieved & $16.5(P<0.001)$ & Not achieved \\
\hline \multirow[t]{3}{*}{ Month 5} & Control & Not achieved & ーーーーーー & Not achieved \\
\hline & Pyrethroid & -ー———-— & 一一一一一- & Not achieved \\
\hline & B. bassiana & Not achieved & $4.4(P=0.037)$ & Not achieved \\
\hline
\end{tabular}

'Not achieved' indicates that the desired level of mortality (Median Lethal Time or $80 \%$ ) was not reached before the end of the 14 day monitoring period. 
(see above) for the duration of their use in each experiment.

\section{Mosquito exposure to the substrates}

A standard WHO cone assay [35] was used for exposing the mosquitoes to the substrates. The plastic cone was secured over each tile and approximately 30 unfed 3-5 day old female mosquitoes introduced. The mosquitoes were left for one hour and then subsequently removed to holding cups (0.33 liter cardboard drinking cups with mosquito mesh cover for the lids) where they were maintained on $10 \%$ glucose water. Each treatment for all assays was replicated four times giving a minimum of 120 mosquitoes per assay. Mortality was monitored daily and dead insects removed from the cages.

\section{Persistence assay 1 - Anopheles stephensi}

The first persistence assay was conducted at Penn State using a long-standing laboratory colony of An. stephensi. Spores of $B$. bassiana were suspended in a mix of mineral oils (80\% Isopar M: 20\% Ondina 22) and the concentration adjusted to give our standard lab dose of $1 \times 10^{9}$ spores $/ \mathrm{ml}$. Fungal spores are lipophylic and this mix of oils acts as a simple carrier with appropriate viscosity for spraying. Spores were applied using a small hand-held pump sprayer clamped horizontally $10 \mathrm{~cm}$ above the test tile. The pump sprayer comprised a pump spray cap (Calmar Inc.) screwed onto a $25 \mathrm{ml}$ glass universal vial. Each tile received five pumps from the sprayer, which delivered a total of $3.5 \mathrm{ml}$ of formulation to give an equivalent dose rate of $3.3 \times 10^{11}$ spores $/ \mathrm{m}^{2}$.

As a positive control we used the pyrethroid insecticide Lambda-cyhalothrin (Chem Service Inc.) at a dose rate of $30 \mathrm{mg} / \mathrm{ml}$ a.i.. Acetone acted as the solvent for the insecticide and silicon oil (Dow Corning 554) served as the carrier. We used technical a.i. in an oil carrier rather than a proprietary formulation, such as a capsulated suspension, because the fungus itself is applied in a simple carrier oil and there are, as yet, no more advanced formulations for comparison. The concentrations were calculated based on the mg of active ingredient per unit of oil [35]. The insecticide was applied in the same manner as the biopesticide to each of the three substrates. Negative controls comprised untreated tiles.

Exposures were performed on Day 1 (i.e. allowing 24 hrs for the treated surfaces to dry) and then every month until the biopesticide failed to hit the $80 \%$ mortality target.

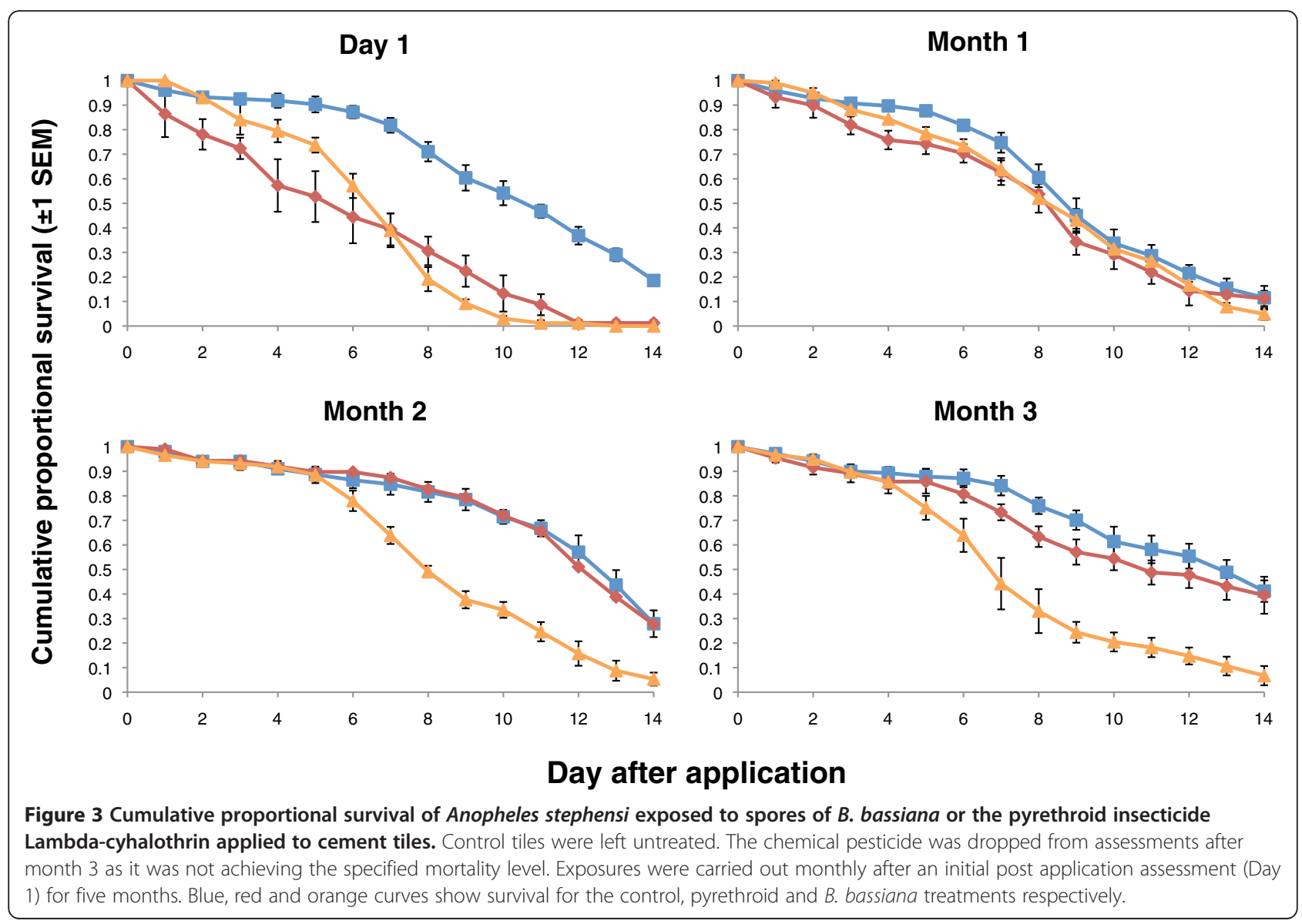


In addition, at five months post spray (when the fungal spray residue had decayed considerably - see results), a repeat exposure experiment was conducted using the clay substrate to simulate what might happen if mosquitoes contacted a treated surface across successive feeding cycles, rather than just once. To do this an extra treatment group was added and exposed to the same treated clay substrate as was used for other exposures. This group was exposed on day 0 , immediately after the single exposure Month 5 group were exposed, and then again three days later, again six days after the initial exposure and finally nine days after the initial exposure. At all other times this group was housed and maintained as all other treatment groups described above.

\section{Persistence assay 2 - Anopheles gambiae}

A repeat persistence study was conducted using $A n$. gambiae (insecticide susceptible SUA strain) at the Vector Control Reference Unit, National Institute for Communicable Diseases, South Africa. The study used the same fungus and substrates and followed the same protocols as described above but because of demands on the insect colony, did not include a pyrethroid as a positive control.

\section{Statistical analysis}

Spore survival during storage was summarized as mean percent germination from the three replicates counted at each time point. A Weibull survival function was fitted to the data for spores incubated at different temperatures for both closed and open storage treatments:

$$
S=\exp \left[-(A / G) t^{G}\right]
$$

where $\mathrm{S}$ is proportional spore germination, $\mathrm{A}$ and $\mathrm{G}$ are best-fit parameters and $t$ is time. These curves were used to estimate the $\mathrm{LT}_{20}$ (i.e. when germination was reduced to $80 \%$, the accepted minimum viability for operational use [44]) and the $\mathrm{LT}_{50}$ (time to 50 percent germination).

Mosquito survival data were analysed using a KaplanMeier survival analysis in SPSS for Mac (v.19) with significant differences between doses and/or treatments estimated using a Log Rank Test.

\section{Results}

\section{Spore viability during storage}

Spores of Beauveria bassiana dried to $5 \%$ moisture content and maintained in sealed aluminium sachets at $7^{\circ} \mathrm{C}$ showed no loss in viability over the monitoring period,

Table 4 Anopheles stephensi survival after exposure to wood tiles

\begin{tabular}{|c|c|c|c|c|}
\hline $\begin{array}{l}\text { Time after } \\
\text { exposure }\end{array}$ & Treatment & $\begin{array}{l}\text { Median Lethal Time in days } \\
\text { (95\% C.I.) }\end{array}$ & $\begin{array}{c}\text { Log rank statistic } \\
\text { (Significance compared to control) }\end{array}$ & $\begin{array}{c}\text { Time to } 80 \% \text { mortality days } \\
( \pm 1 \text { SEM) }\end{array}$ \\
\hline \multirow[t]{3}{*}{ Day 1} & Control & $10.0(9.34-10.66)$ & -—————- & $12.8( \pm 0.48)$ \\
\hline & Pyrethroid & $1.0(0.00-0.00)$ & $198.7(P<0.001)$ & $1.0( \pm 0.00)$ \\
\hline & B. bassiana & $4.0(3.64-4.37)$ & $105.7(P<0.001)$ & $5.5( \pm 0.87)$ \\
\hline \multirow[t]{3}{*}{ Week 1} & Control & $10.0(7.38-12.63)$ & -—-—-—- & Not achieved \\
\hline & Pyrethroid & $1.0(0.00-0.00)$ & $36.6(P<0.001)$ & $10.5( \pm 2.02)$ \\
\hline & B. bassiana & $4.0(3.76-4.25)$ & $65.5(P<0.001)$ & $5.8( \pm 0.75)$ \\
\hline \multirow[t]{3}{*}{ Month 1} & Control & $9.0(7.82-10.19)$ & -二-二-— & $12.3( \pm 0.48)$ \\
\hline & Pyrethroid & $1.0(0.00-0.00)$ & $107.9(P<0.001)$ & $3.0( \pm 1.22)$ \\
\hline & B. bassiana & $7.0(6.05-7.59)$ & $3.5(P=0.060)$ & $11.5( \pm 1.04)$ \\
\hline \multirow[t]{3}{*}{ Month 2} & Control & $11.0(10.14-11.86)$ & -—-二-—- & Not achieved \\
\hline & Pyrethroid & $1.0(0.00-0.00)$ & $88.19(P<0.001)$ & $5.0( \pm 2.31)$ \\
\hline & B. bassiana & $7.0(6.46-7.54)$ & $80.4(P<0.001)$ & $9.3( \pm 0.75)$ \\
\hline \multirow[t]{3}{*}{ Month 3} & Control & $10.0(9.07-10.93)$ & -二-——- & Not achieved \\
\hline & Pyrethroid & $9.0(8.25-9.75)$ & $5.7(P=0.017)$ & $7.5( \pm 3.75)$ \\
\hline & B. bassiana & $4.0(3.74-4.26)$ & $168.7(P<0.001)$ & Not achieved \\
\hline \multirow[t]{3}{*}{ Month 4} & Control & Not achieved & - - - - - & Not achieved \\
\hline & Pyrethroid & Not achieved & $41.9(P<0.001)$ & Not achieved \\
\hline & B. bassiana & Not achieved & $11.3(P=0.001)$ & Not achieved \\
\hline \multirow[t]{3}{*}{ Month 5} & Control & Not achieved & -二-—-二- & Not achieved \\
\hline & Pyrethroid & $2.0(1.69-2.31)$ & $122.9(P<0.001)$ & Not achieved \\
\hline & B. bassiana & Not achieved & $0.92(P=0.34)$ & Not achieved \\
\hline
\end{tabular}


with spore germination rate of $98.1 \pm 0.55 \%$ after 750 days (Figure 1A, B).

Spores taken from refrigeration and placed at different temperatures showed a clear temperature dependent decline in viability (Figure 1A), with decay half-lives of 31, 49 and 71 days for $32^{\circ} \mathrm{C}, 26^{\circ} \mathrm{C}$ and $22^{\circ} \mathrm{C}$, respectively (Table 1 ).

Removal from refrigeration to warm temperatures and high ambient humidity also resulted in decline in viability (Figure 1B), although decay rates were relatively slower for the cooler temperatures than under sealed conditions $\left(\mathrm{LT}_{50 \mathrm{~s}}\right.$ of 67 and 117 days for $26^{\circ} \mathrm{C}$ and $22^{\circ} \mathrm{C}$, respectively (Table 1$)$ ).

\section{Fungal persistence following application \\ Assay 1 - An. stephensi}

Spray applications of B. bassiana achieved $80 \%$ mortality for four months on the clay substrate (Table 2 and Figure 2). At month five An. stephensi survival was still significantly less than control survival but did not decline below $20 \%$ by the end of the 14 day assessment period. Repeated exposure of mosquitoes on a three day 'feeding cycle', however, restored efficacy and resulted in $80 \%$ by day 13 (Table 2 and Figure 2). In contrast the pyrethroid Lambda-cyhalothrin performed very poorly on clay, with no obvious knockdown and very little difference in overall survival to the control group. The insecticide was dropped from assessments after month 3.

On cement, $80 \%$ mortality was achieved for three months, though mosquitoes were clearly infected up to month 5 as indicated by survival differences relative to controls (Table 3 and Figure 3). Similar to the clay substrate, after the initial assessment on day 1, the pyrethroid performed poorly on cement and was dropped from assessments after 3 months.

On wood, $80 \%$ mortality was achieved for 2 months with evidence of infection up to month 4 (Table 4 and Figure 4). In contrast to the other two substrates the pyrethroid generally produced rapid mortality in the mosquitoes twenty-four hours after exposure. The absolute level of mortality achieved was variable with 100\% mortality achieved within 24 hours of exposure on day 1 but only $22 \%$ mortality in month 4 .

Overall there was quite large and unexpected variation in control survival between months. This sometimes obscured treatment effects. For example, in month 1 on concrete there was no difference between fungus and controls because control mortality was high. There was

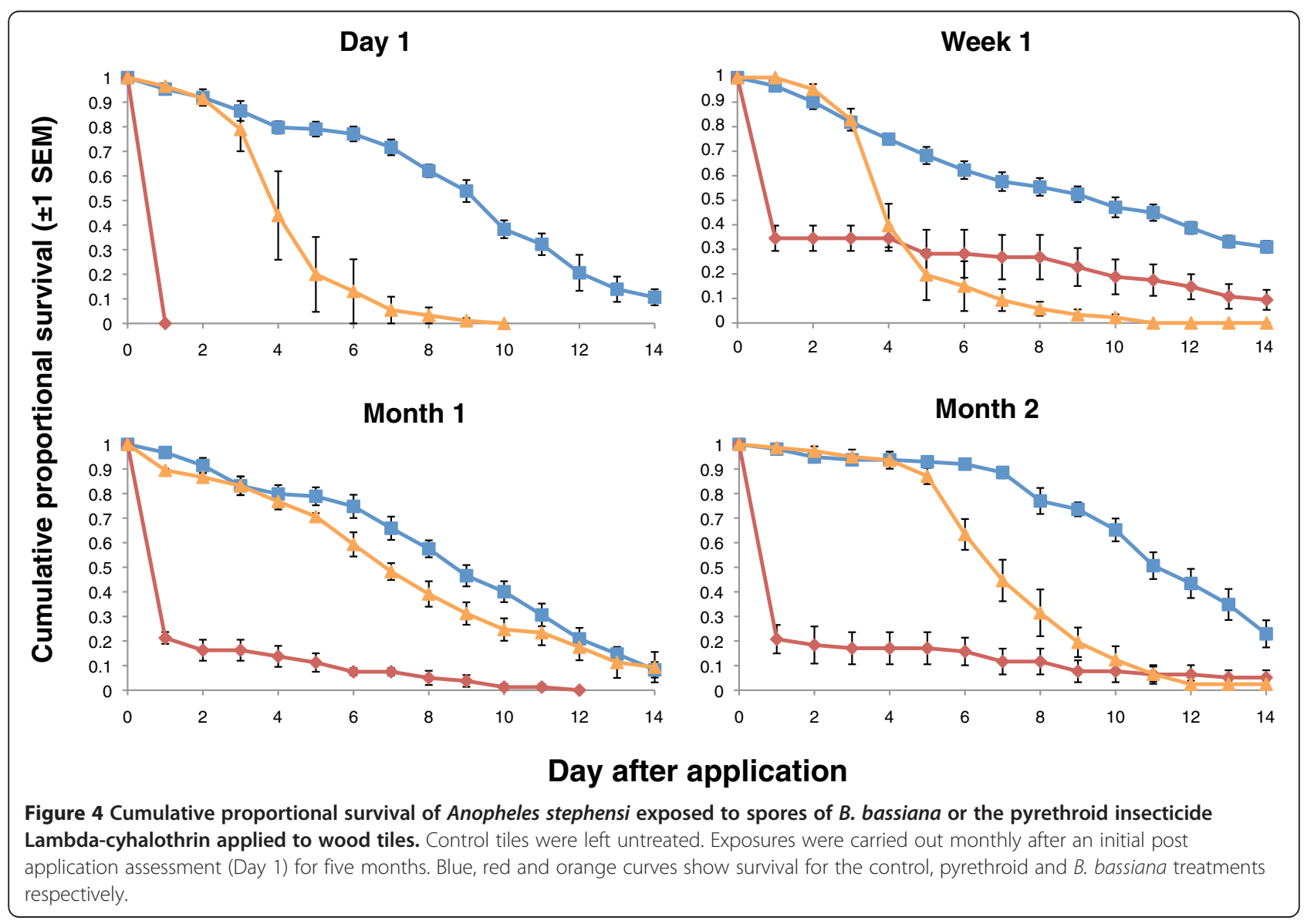


a clear effect of fungus in subsequent months as control survivorship improved.

\section{Assay 2 - An. gambiae}

Exposure to spores on the clay substrate produced $>80 \%$ mortality up to month 5 . Unfortunately an accident in the lab compromized the collection of the month 6 data. At month 7 the day 14 mortality was still considerable but had dropped to around 68\% (Table 5 Figure 5).

On the cement and wood substrates, fungal exposed insects demonstrated significantly higher mortality than controls up to month 3 but never achieved the $80 \%$ mortality target (Tables 6 and 7). Accordingly, exposures were not conducted beyond month 3 for these treatments.

\section{Discussion}

Spores of Beauveria bassiana stored under ideal conditions of low moisture content and low temperature survived with no loss of viability for over two years. Assuming access to cold storage, this baseline viability meets the WHO pesticide shelf-life criterion [27]. Once removed from refrigeration spore viability declined in a temperature dependent manner with high temperatures resulting in a faster rate of mortality than cooler temperatures. Surprisingly, under open storage, where the spore powder was exposed to high humidity in the incubators, survival was better than when spores were protected from humidity. Why this was so is unclear as maintaining low moisture content should improve spore stability [32]. Nonetheless, these results suggest the need for relatively rapid distribution and use of product once taken out of some sort of long-term stockpile. Such an approach is similar to standard practice for the mosquito larval biocontrol agent, Bacillus thuringiensis [45-47]. Moreover, certain commercial preparations of B. bassiana used in agriculture exhibit shelf lives of 12 months or more at room temperature [33,34,48], so there is scope for more product development. Further, data from other storage studies suggest that the viability of spores under variable temperature conditions (i.e. not refrigeration) might depend on the absolute age of the spores [44]. The current experiments used spores that had already been in storage for 585 days. Taking spores from storage at perhaps three or six months after production could potentially alter viability/persistence downstream. Assuming there is some sort of trade-off, optimizing time spent in storage $v s$ time available for distribution and use will be an important factor in supply chain management.

Spore persistence following application varied considerably between substrates and assays. With the An. stephensi assays the control mortality was higher and much more variable than expected, making interpretation of results slightly difficult on some occasions. However, effective persistence was clearly demonstrated up to 4 months on clay substrates (and this could be extended to five months if mosquitoes contacted the treated substrates more than once). Persistence on cement and wood were less good, but $80 \%$ morality was still achieved up to months 2 and 3, respectively. Persistence of $2-4$ months is within the range of existing chemical insecticides approved for use in IRS by the WHO [36,37].

Table 5 Anopheles gambiae survival after to clay tiles

\begin{tabular}{|c|c|c|c|c|}
\hline Time after exposure & Treatment & $\begin{array}{l}\text { Median Lethal Time in days } \\
\text { (95\% C.I.) }\end{array}$ & $\begin{array}{c}\text { Log rank statistic } \\
\text { (Significance compared to control) }\end{array}$ & $\begin{array}{c}\text { Time to } 80 \% \text { mortality days } \\
\text { ( } \pm 1 \text { SEM) }\end{array}$ \\
\hline \multirow[t]{2}{*}{ Day 1} & Control & Not achieved & -————— & Not achieved \\
\hline & B. bassiana & $5.0(4.81-5.19)$ & $209.0(P<0.001)$ & $5.8( \pm 0.48)$ \\
\hline \multirow[t]{2}{*}{ Month 1} & Control & Not achieved & -—-—-—- & Not achieved \\
\hline & B. bassiana & $4.0(3.85-4.15)$ & $185.9(P<0.001)$ & $4.5( \pm 0.29)$ \\
\hline \multirow[t]{2}{*}{ Month 2} & Control & Not achieved & -——-——- & Not achieved \\
\hline & B. bassiana & $5.0(4.72-5.28)$ & $208.1(P<0.001)$ & $6.3( \pm 0.25)$ \\
\hline \multirow[t]{2}{*}{ Month 3} & Control & Not achieved & -—-ー-—— & Not achieved \\
\hline & B. bassiana & $6.0(5.71-6.29)$ & $219.6(P<0.001)$ & $7.0( \pm 0.00)$ \\
\hline \multirow[t]{2}{*}{ Month 4} & Control & Not achieved & -—————- & Not achieved \\
\hline & B. bassiana & $8.0(7.53-8.47)$ & $236.9(P<0.001)$ & $9.5( \pm 0.65)$ \\
\hline \multirow[t]{2}{*}{ Month 5} & Control & Not achieved & -——-—— & Not achieved \\
\hline & B. bassiana & $10.0(9.48-10.52)$ & $155.4(P<0.001)$ & $9.5( \pm 0.65)$ \\
\hline Month 6 & \multicolumn{4}{|c|}{ No assessments made } \\
\hline \multirow[t]{2}{*}{ Month 7} & Control & Not achieved & -二-———- & Not achieved \\
\hline & B. bassiana & $11.0(10.04-11.96)$ & $55.5(P<0.001)$ & Not achieved \\
\hline
\end{tabular}

'Not achieved' indicates that the desired level of mortality (Median Lethal Time or $80 \%$ ) was not reached before the end of the 14 day monitoring period. 


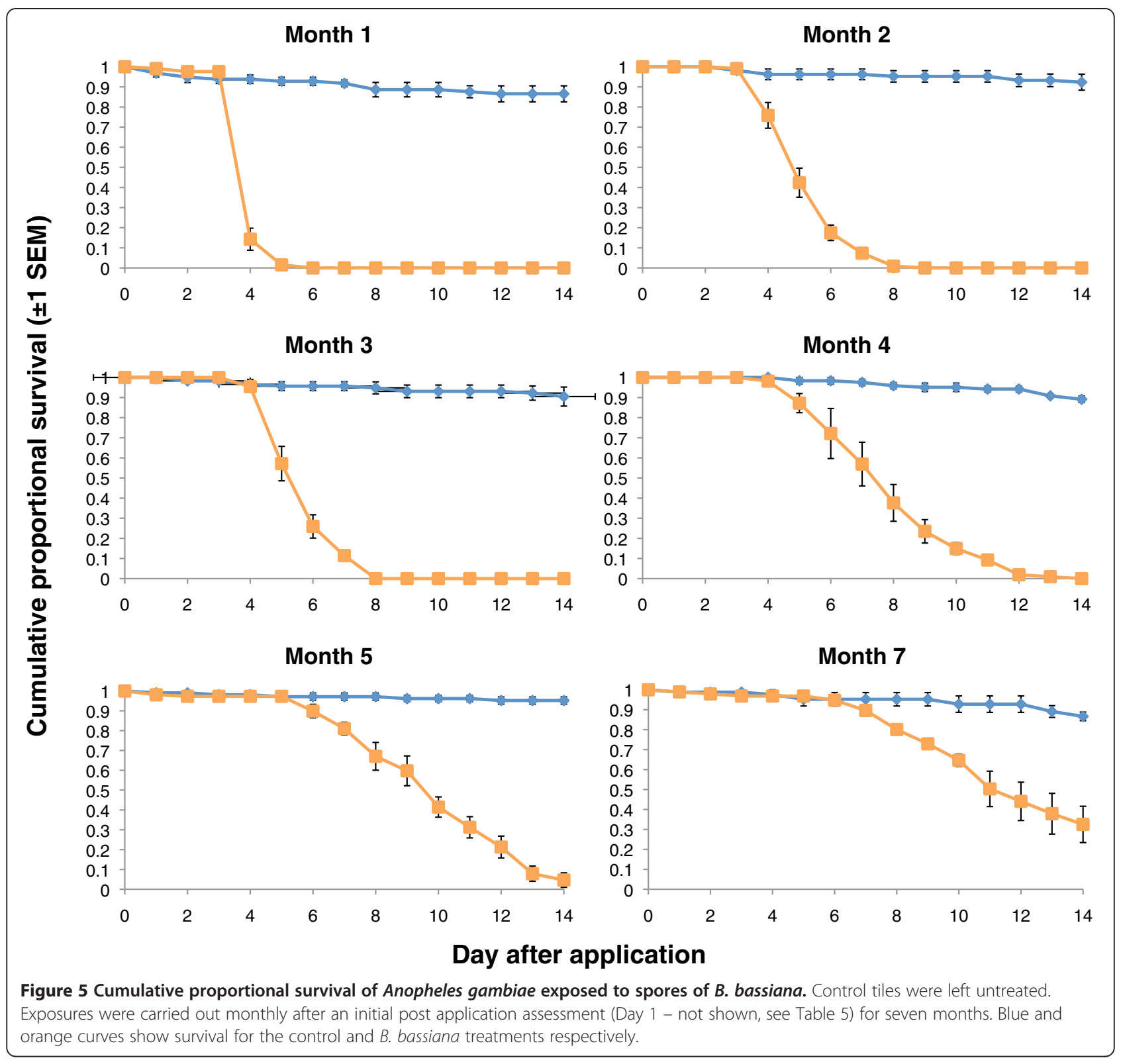

Table 6 Anopheles gambiae survival after exposure to cement tiles

\begin{tabular}{|c|c|c|c|c|}
\hline Time after application & $\begin{array}{c}\text { Dose and } \\
\text { Formulation }\end{array}$ & $\begin{array}{l}\text { Median Lethal Time in days } \\
(95 \% \text { C.I. })\end{array}$ & $\begin{array}{c}\text { Log rank statistic } \\
\text { (Significance compared to control) }\end{array}$ & $\begin{array}{l}\text { Time to } 80 \% \text { mortality days } \\
\text { ( } \pm 1 \text { SEM) }\end{array}$ \\
\hline \multirow[t]{2}{*}{ Day 1} & Control & Not achieved & -—————- & Not achieved \\
\hline & B. bassiana & $12.0(10.28-13.72)$ & $28.1(P<0.001)$ & Not achieved \\
\hline \multirow[t]{2}{*}{ Month 1} & Control & Not achieved & -ー-——- & Not achieved \\
\hline & B. bassiana & Not achieved & n.s. & Not achieved \\
\hline \multirow[t]{2}{*}{ Month 2} & Control & Not achieved & -二-——- & Not achieved \\
\hline & B. bassiana & Not achieved & $12.6(P<0.001)$ & Not achieved \\
\hline \multirow[t]{2}{*}{ Month 3} & Control & Not achieved & 一-二-二- & Not achieved \\
\hline & B. bassiana & Not achieved & $19.0(P<0.001)$ & Not achieved \\
\hline
\end{tabular}


Table 7 Time of exposure, formulation and dose details and Anopheles gambiae survival estimates following exposure to Beauveria bassiana spores applied to a wood substrate

\begin{tabular}{|c|c|c|c|c|}
\hline Time after application & $\begin{array}{c}\text { Dose and } \\
\text { Formulation }\end{array}$ & $\begin{array}{l}\text { Median Lethal Time in days } \\
(95 \% \text { C.I.) }\end{array}$ & $\begin{array}{l}\text { Log rank statistic } \\
\text { (Significance compared to control) }\end{array}$ & $\begin{array}{l}\text { Time to } 80 \% \text { mortality days } \\
\text { ( } \pm 1 \text { SEM) }\end{array}$ \\
\hline \multirow[t]{2}{*}{ Day 1} & Control & Not achieved & 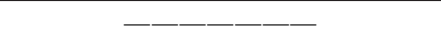 & Not achieved \\
\hline & B. bassiana & Not achieved & $9.1(P<0.003)$ & Not achieved \\
\hline \multirow[t]{2}{*}{ Month 1} & Control & Not achieved & -——-—— & Not achieved \\
\hline & B. bassiana & Not achieved & $4.9(P=0.027)$ & Not achieved \\
\hline \multirow[t]{2}{*}{ Month 2} & Control & Not achieved & ーーーーー—ー & Not achieved \\
\hline & B. bassiana & Not achieved & $19.1(P<0.001)$ & Not achieved \\
\hline \multirow[t]{2}{*}{ Month 3} & Control & Not achieved & -—————— & Not achieved \\
\hline & B. bassiana & Not achieved & n.s. & Not achieved \\
\hline
\end{tabular}

'Not achieved' indicates that the desired level of mortality (50\% - Median Lethal Time, or $80 \%$ ) was not reached before the end of the 14 day monitoring period.

Indeed, the fungus performed considerably better on the clay and concrete substrates than a basic formulation of Lambda-cyhalothrin, which essentially had no impact from month 1 (or even day 1 on clay). Performance of the chemical was much better on wood. These results are consistent with previous observations that porous substrates such as clay can interfere with the pick-up of chemical insecticides $[37,49,50]$.

Control survival in the An. gambiae assays was much more stable, leaving treatment effects unambiguous. On clay tiles the fungal spray residue remained effective for between 5-7 months (the pattern of the mortality data suggest the month 6 exposure would have achieved the $80 \%$ cut off, but unfortunately the month 6 samples were not available). On wood and cement tiles, on the other hand, while there was some significant mortality relative to controls for up to 3 months, mortality of $80 \%$ was never achieved even from day 1.

The reasons for the differences in persistence and efficacy of fungal spray residues between substrates are unclear and we have no satisfactory explanation as to why spray applications on both wood and cement produced such different results between assays. Physical removal of spores from the substrates by mosquitoes could have occurred but did not obviously contribute to the patterns of decline we saw (i.e. the substrates that remained viable longest actually had the greatest number of repeat exposures). Cement is strongly alkaline and it is possible that this impacted spore survival relative to clay. High $\mathrm{pH}$ has been shown to affect persistence of chemical active ingredients [50]. The poorer effective persistence on wood was slightly more surprising as we had expected it to be a relatively inert, non-absorptive substrate. A previous study examining long-term survival of spores of the current fungal isolate sprayed on glass slides (also inert and non porous), reported a half-life $>3$ months [51]. It is possible, therefore, that the commercial plywood we used had some sort of chemical treatment that affected spore viability. Our attempts to verify with the seller that the plywood was completely free of antifungal chemicals were unsuccessful. There are no recommendations in the WHOPES guidelines for exactly what sort of substrates to test beyond wood, clay and cement. Further studies examining different types of these basic substrates would be worthwhile.

Overall, the results of the current study are extremely encouraging. Fungal spores can be produced and stored without loss of viability for $>2$ years. The fungus is a living organism and once removed from storage, spores are relatively sensitive to temperature but there appears scope for further product development work to improve stability, as well as options for appropriate supply chain management similar to that used for other biologicals. Once sprayed, simple oil formulations can persist as long as some of the standard chemical insecticides. Performance on clay was especially good, which is encouraging as the porous properties of clay/mud are challenging for chemical insecticides. Performance on the other substrates was more variable, but no more so than the basic wettable powder formulation of Lambda-cyhalothrin, which is one of the most widely used chemicals in IRS $[52,53])$. More advanced formulations of Lambda-cyhalothrin, such as capsulated suspensions, have been developed and shown to enhance performance in the field $[52,53]$. It is highly likely that with equivalent research effort, novel formulations of fungal pathogens (including microencapsulation [54-56]) could also be developed to further improve shelf life and persistence. Furthermore, in line with WHO protocols, assessments in the current study focused on mortality effects alone. While conventional chemicals based on fast-acting neurotoxins do result in rapid death, slower speed of kill (i.e. high mortality by day 14 when mosquitoes could conceivably transmit malaria) is sufficient to provide good malaria control assuming good product coverage see [24-26]. Moreover, it has been demonstrated that sub- or prelethal effects of fungal infection can add to mortality to reduce transmission potential further $[6,7,23]$. As such, 
it is probable that levels of persistence reported here are underestimates of overall effective persistence.

\section{Competing interests}

The authors declare that they have no competing interests.

\section{Authors' contributions}

$\mathrm{SB}, \mathrm{AFR}$ and MBT conceived and designed the experiments. SB, BHKC, RC, $\mathrm{OM}$ and $\mathrm{NL}$ conducted the experiments. NEJ, LK, MC provided fungal and entomological materials and laboratory resources. SB analysed the results. SB, AFR and MBT drafted the manuscript. All authors read and approved the final manuscript.

\section{Acknowledgements}

This research was part-funded by grants from Gates Grand Challenges Explorations (No. 53066), the National Institutes of Health (Al088094-01), the Innovative Vector Control Consortium and by the Research and Policy for Infectious Disease Dynamics (RAPIDD) program. This project was also funded, in part, under a grant with the Pennsylvania Department of Health using Tobacco Settlement Funds. The Department specifically disclaims responsibility for any analyses, interpretations or conclusions. All funders had no role in study design, data collection and analysis, decision to publish, or preparation of the manuscript.

\section{Author details}

'Center for Infectious Disease Dynamics, Penn State University, Department of Biology, Mueller Laboratory, University Park, PA 16802, USA. ${ }^{2}$ Center for Infectious Disease Dynamics, Department of Entomology, Penn State University, Merkle Lab, University Park, PA 16802, USA. ${ }^{3}$ Vector Control Reference Unit, National Institute for Communicable Diseases of the NHLS, Private Bag X4, Sandringham, Johannesburg 2131, South Africa. ${ }^{4}$ Malaria Entomology Research Unit, School of Pathology, Faculty of Health Sciences, University of Witwatersrand, Johannesburg, South Africa. ${ }^{5}$ Fogarty

International Center, National Institutes of Health, Bethesda, MD 20892, USA

Received: 24 August 2012 Accepted: 18 October 2012

Published: 25 October 2012

\section{References}

1. Zaim M, Guillet P: Alternative insecticides: an urgent need. Trends Parasitol 2002, 18:161-163.

2. Nauen R: Insecticide resistance in disease vectors of public health importance. Pest Manag Sci 2007, 63:628-633.

3. Ranson H, N'Guessan R, Lines J, Moiroux N, Nkuni Z, Corbel V: Pyrethroid resistance in African anopheline mosquitoes: what are the implications for malaria control? Trends Parasitol 2011, 27:91-98.

4. Chandra E, Hemingway J, Kleinschmidt I, Rehmna AM, Ramdeen V, Phiri FN, Coetzer S, Mthembu D, Shinondo CJ, Chizema-Kawesha E, Kamuliwo M, Mukonka V, Baboo KS, Coleman M: Insecticide resistance and the future of malaria control in Zambia. PLoS One 2011, 6:e24336.

5. Asidi S, N'Guessan R, Akogbeto M, Curtis C, Rowland M: Loss of household protection from use of insecticide-treated nets against pyrethroidresistant mosquitoes, Benin. Emerg Infect Dis 2012, 18:1101-1106.

6. Blanford S, Chan BHK, Jenkins N, Sim D, Turner RJ, Read AF, Thomas MB: Fungal pathogen reduces potential for malaria transmission. Science 2005, 308:1638-1641.

7. Blanford S, Wangpeng S, Christian R, Marden JH, Koekemoer LL, Brooke BD, Coetzee M, Read AF, Thomas MB: Lethal and pre-lethal effects of a fungal biopesticide contribute to substantial and rapid control of malaria vectors. PLoS One 2011, 6:e23591.

8. McMeniman CJ, Lane RV, Cass BN, Fong AWC, Sidhu M, Wang Y-F, O'Neill SL: Stable introduction of a life-shortening Wolbachia infection into the mosquito Aedes aegypti. Science 2009, 323:141-144.

9. Ren XX, Rasgon JL: Potential for the Anopheles gambiae densonucleosis virus to act as an "Evolution-Proof" biopesticide. J Virology 2010, 84:7726-7729.

10. Lorenz LM, Koella JC: The microsporidian parasite Vavraia culicis as a potential late life-acting control agent of malaria. Evolutionary Applications 2011, 4:783-790.
11. Scholte E-J, Ng'Habi K, Kihonda J, Takken W, Paiijmans K, Abdulla S, Killeen GF, Knols BGJ: An entomopathogenic fungus for control of adult African malaria mosquitoes. Science 2005, 308:1641-1643.

12. Scholte EJ, Takken W, Knols BGJ: Infection of adult Aedes aegypti and Ae. albopictus mosquitoes with the entomopathogenic fungis Metarhizium anisopliae. Acta Trop 2007, 102:151-158.

13. Achonduh OA, Tondje PR: First report of pathogenicity of Beauveria bassiana RBL1034 to the malaria vector, Anopheles gambiae s.l. (Diptera: Culicidae) in Cameroon. African J Biotechnol 2008, 7:931-935.

14. Mohanty SS, Raghavendra K, Rai U, Dash AP: Efficacy of female Culex quinquefasciatus with entomopathogenic fungus Fusarium pallidoroseum. Parasitol Res 2008, 103:171-174.

15. De Paula AR, Brito ES, Pereira CR, Carrera MP, Samuels RI: Susceptibility of adult Aedes aegypti (Diptera: Culicidae) to infection with Metarhizium anisopliae and Beauveria bassiana: prospects for dengue control. Biocontrol Science and Technol 2008, 18:1017-1025.

16. Mnyone LL, Russell TL, Lyimo IN, Lwetoijera DW, Kirby MJ, Luz C: First report of Metarhizium anisopliae IP 46 pathogenicity tin adult Anopheles gambiae s.s. and An. arabiensis (Diptera: Culicidae). Parasit Vectors 2009, 2:59.

17. Farenhorst M, Mouatcho JC, Kikankie CK, Brooke BD, Hunt RC, Thomas MB, Koekemoer LL, Knols BGJ, Coetzee M: Fungal infection counters insecticide resistance in African malaria mosquitoes. Proc Natl Acad Sci USA 2009, 106:17443-17447.

18. Howard AFV, N'Guessan R, Koenraadt C, Asidi A, Farnehorst M, Akogbeto M, Knols BGJ, Takken W: First report of the infection of insecticide-resistant malaria vector mosquitoes with an entomopathogenic fungus under field conditions. Malar J 2011, 10:24.

19. Mnyone LL, Lyimo IN, Lwetoijera DW, Mpingwa MW, Nchimbi N, Hancock PA, Russell TL, Kirby MJ, Takken W, Koenraadt CJM: Exploiting the behaviour of wild malaria vectors to achieve high infection with fungal biocontrol agents. Malar J 2012, 11:87.

20. Mnyone LL, Kirby MJ, Lwetoijera DW, Mpinga MW, Knols BGJ, Takken W, Russell TL: Infection of the malaria mosquito, Anopheles gambiae, with two species of entomopathogenic fungi: effects of concentration, formulation, exposure time and persistence. Malar J 2009, 8:309.

21. Farenhorst M, Farina D, Scholte EJ, Takken W, Hunt RH, Coetzee M, Knols $B G J$ : African water storage pots for the delivery of the entomopathogenic fungus Metarhizium anisopliae to the malaria vectors Anopheles gambiae s.s. and Anopheles funestus. AmJTrop Med Hyg 2008, 78:910-916.

22. Farenhorst M, Hilhorst A, Thomas MB, Knols BGJ: Development of fungal applications on netting substrates for malaria vector control. J Med Entomol 2011, 48:305-313.

23. George J, Blanford S, Domingue MJ, Thomas MB, Read AF, Baker TC: Reduction in host-finding behaviour in fungus-infected mosquitoes is correlated with reduction in olfactory receptor neuron responsiveness. Malar J 2011, 10:219.

24. Hancock PA: Combining fungal biopesiticides and insecticide-treated bednets to enhance malaria control. PLOS Comput Biol 2009, 5:e10000525.

25. Hancock PA, Thomas MB, Godfray HCJ: An age-structured model to evaluate the potential of novel malaria-control interventions: a case study of fungal biopesticide sprays. Proc R Soc Lond B 2009, 276:71-80

26. Read AF, Lynch PA, Thomas MB: How to make evolution-proof insecticides for malaria control. PLoS Biol 2009, 7:e1000058.

27. WHO: Manual on development and use of FAO and WHO specifications for pesticides. 2010. http://www.fao.org/ag/AGP/AGPP/Pesticid/Specs/Pdf/ Manual_update\%202006.pdf.

28. CropLife International: Guidelines for specifying the shelf life of plant protection products. Technical Monograph No. 17. 2nd edition. Brussels: Croplife International, Brussels; 2009:10.

29. Daoust RA, Roberts DW: Studies on the prolonged storage of Metarhizium anisopliae conidia: Effect of temperature and relative humidity on conidial viability and virulence against mosquitoes. J Invert Pathol 1983, 41:143-150

30. Hong TD, Gunn J, Ellis RH, Jenkins NE, Moore D: The effect of storage environment on the longevity of conidia of Beauveria bassiana. Mycol Res 2001, 105:597-602.

31. Hong TD, Ellis RH, Moore D: Development of a model to predict the effect of temperature and moisture on fungal spore longevity. Ann Botany 1997, 79:121-128. 
32. Hong TD, Jenkins $\mathrm{NE}$, Ellis $\mathrm{RH}$ : Fluctuating temperature and the longevity of conidia of Metarhizium flavoviride in storage. Biocontr Sci Technol 1999, 9:165-176.

33. Faria $M$, Hotchkiss JH, Wraight SP: Application of modified atmosphere packaging (gas flushing and active packaging) for extending the shelf life of Beauveria bassiana conidia at high temperatures. Biol Contr 2012, 61:78-88.

34. Oliveira I, Pereira JA, Bento A, Baptista P: Viability of Beauveria bassiana isolates after storage under several preservation methods. Annals Microbiol 2011, 61:339-344.

35. WHO: Guidelines for testing mosquito adulticides for indoor residual spraying and treatment of mosquito nets. Rome: World Health Organization; 2006. WHO/CDS/NTD/WHOPES/GCDPP/2006.3.

36. WHO: WHO recommended insecticides for indoor spraying against malaria vectors. 2007. http://www.who.int/whopes/Insecticides_IRS_Malaria_ok.pdf.

37. Najera JA, Zaim M: Insecticides for indoor residual spraying. 2011. http:// whqlibdoc.who.int/hq/2001/WHO_CDS_WHOPES_2001.3.pdf.

38. Pilz C, Enkerli J, Wegensteiner R, Keller S: Establishment and persistence of the entomopathogenic fungus Metarhizium anisopliae in maize fields. J Appl Entomol. 2011, 135:393-403.

39. Thomas MB, Wood SN, Langewald J, Lomer CJ: Persistence of Metahizium flavoviride and consequences for biological control of grasshoppers and locusts. Pestic Sci 1997, 49:47-37.

40. Kooyman C, Bateman RP, Langewald J, Lomer CJ, Ouambama Z: Operational-scale application of entomopathogenic fungi for control of Sahelian grasshoppers. Proc R Soc Lond B 1997, 264:541-546.

41. Moore D, Higgins PM, Lomer CJ: Effects of simulated and natural sunlight on the germination of conidia of Metarhizium flavoviride and interactions with temperature. Bicontr Sci Technol 1996, 6:63-76.

42. Milner RJ, Samson P, Morton R: Persistence of conidia of Metarhizium anisopliae in sugarcane fields: effects of isolate and formulation on persistence over 3.5 years. Biocontr Sci Technol 2003, 13:507-516.

43. Vanninen I, Tyni-Juslin J, Hokkanen H: Persistence of augmented Metarhizium anisopliae and Beauveria bassiana in Finnish agricultural soils. Biocontrol 2000, 45:201-222

44. Jenkins NE, Grzywacz D: Towards the standardization of quality control of fungal and viral biocontrol agents. In Quality Control and Production of Biological Control Agents: Theory and testing Procedures. Edited by van Lenteren JC. Wallingford: CAB International; 2003:247-263.

45. Lacey LA: Bacillus thuringiensis serovariety israelensis and Bacillus sphaericus for mosquito control. J. Am. Mosquito Contr 2007, 23:133-163.

46. Manonmani AM, Prabakan G, Hoti SL: Retention of mosquito larvidical activity of lyophilized cells and WDP formulation of Bacillus thuringiensis var. israelensis on long-term storage. Acta Trop 2008, 105:170-175.

47. Prabakaran G, Hoti SL: Immobilization in alginate as a technique for the preservation of Bacillus thuringiensis var. israelensis for long-term preservation. J. Microbiol. Meth 2008, 72:91-94.

48. Jackson MA, Dunlap CA, Jaronski ST: Ecological considerations in producing and formulating fungal entomopathogens for use in insect biocontrol. BioControl 2010, 55:129-145.

49. Singh K, Rahman SJ, Joshi GC: Village scale trials of deltamethrin against mosquitoes. J Commun Dis 1989, 21:339-353.

50. Vantandoost MR, Abai M, Abbasi M, Shaegi M, Abtahi M, Rafie F: Designing of a laboratory model for evaluation of the residual effects of deltamethrin (Kothrine WP 5\%) on different surfaces against malaria vector, Anopheles stephensi (Diptera: Culicidae). J Vector Dis 2009, 46:261-267.

51. Darbro JM, Thomas MB: Spore persistence and likelihood of aeroallergenicity of entomopathogenic fungi used for mosquito control. AmJTrop Med Hyg 2009, 80:992-997.

52. Raghavendra K, Ghosh SK, Eapen A, Tiwari SN, Satyanarayan TS, Ravindran J, Sreehari U, Dash AP: Field evaluation of lambda-cyhalothrin (ICON 10 CS) indoor residual spraying against Anopheles culicifacies in India. J Vector Borne Dis 2011, 48:18-26.

53. WHO: Report of the tenth WHOPES working group meeting. Review of: Spinosad 0.5\% GR and 12 SC, Lambda-cyhalothrin 10\% CS, K-O Tab 1-2-3 and Interceptor. Rome: World Health Organization; 2007. WHO/CDS/NTD/ WHOPES/2007.1.

54. Leland JE, Behle RW: Coating Beauveria bassiana with lignin for protection from solar radiation and effects on pathogenicity to Lygus lineolaris (Heteroptera: Miridae). Biocontr Sci Technol 2005, 15:309-320.
55. Liu CP, Liu SD: Formulation and characterization of the microencapsulated entomopathogenic fungus Metarhizium anisopliae MA126. J Microencapsulation 2009, 26:377-384.

56. Winder RS, Wheeler JJ, Conder N, Otvos IS, Nevill R, Duan L: Microencapsulation: a strategy for formulation of inoculum. Biocontr SCi Technol 2003, 13:155-169.

doi:10.1186/1475-2875-11-354

Cite this article as: Blanford et al:: Storage and persistence of a candidate fungal biopesticide for use against adult malaria vectors. Malaria Journal 2012 11:354

\section{Submit your next manuscript to BioMed Central and take full advantage of:}

- Convenient online submission

- Thorough peer review

- No space constraints or color figure charges

- Immediate publication on acceptance

- Inclusion in PubMed, CAS, Scopus and Google Scholar

- Research which is freely available for redistribution

Submit your manuscript at www.biomedcentral.com/submit
C) Biomed Central 